\title{
RESENHA:
}

\section{Intermitências da morte}

\author{
Elisabete Peiruque \\ Universidade Federal do Rio Grande do Sul
}

Único ser vivo a ter consciência de sua finitude, o homem tenta encontrar consolo - ou afastar o medo talvez - falando da morte e de sua inevitabilidade. Por ser ela uma constante na sua experiência da vida antes de se tornar o fim para ele próprio, elabora teorias filosóficas e cria formas artísticas sobre o enigma do sentido de viver para morrer. A vida inclui a morte que o homem não deixará jamais de rejeitar, mesmo tendo consciência da impossibilidade de viver para sempre. "O homem é a criança enlouquecida diante da morte" (Leneru, apud Morin, O homem e a morte, 1970, p. 269). Um olhar para a história das artes mostra pinturas e obras literárias cuja temática é a morte, aparecendo freqüentemente como começou a ser representada a partir do século XII, isto é, o esqueleto coberto por um manto monástico e uma foice na mão. Essa é assim uma das formas pela qual a morte surge no romance de José Saramago, Intermitências da morte.

Como realidade invisível, porém implacável, ela é o centro dos dois núcleos que constituem o romance do autor português. Sua ausência desencadeia - em um espaço sem nome e num tempo não datado, mas que certamente se trata do nosso por uma série de indícios - uma catástrofe em termos romanescos, o que leva o leitor a pensar na real necessidade da morte para a renovação da vida. Mesclando situações absurdas, impossíveis, com outras que seriam realidades caso os homens não morressem, Saramago mostra um mundo ambíguo formado por milhões de pessoas que, eufóricas porque a morte desapareceu de seus horizontes, sentem-se paradoxalmente aliviadas quando ela volta a ser uma presença, independente da suas vontades e atos.

Seguindo-se a essa verdadeira reportagem, ainda que fantástica, onde a ironia reina pela voz do narrador, o romance desenvolve um segundo núcleo onde o leitor vê tanto a imagem tradicional da morte como a sua transfiguração numa bela mulher que decide verificar o que impede que a comunicação sobre uma morte próxima chegue a seu destino, um violoncelista. A partir do não-lugar em que vive, a figura mortal que comanda os destinos do mundo envia uma fatídica e temida correspondência sob a forma de uma carta lilás para os homens que sabem então estar com seus dias contados.

O romance de Saramago, neste segundo momento, é atravessado por uma outra espécie de ironia quando a mulher-morte se apaixona pela vida e decide adiar o fim daquele que estava marcado para morrer porque ela passa a amá-lo. Mais especificamente, conhece os prazeres do sexo e não quer abrir mão deles. A situação é irônica traduzindo uma postura de desmistificação da morte, algo como um enfrentamento para afastar o horror.

A obra de Saramago integra um largo espectro de imagens artísticas da morte que fazem fortuna ao longo do tempo por representarem as apreensões da alma humana desde sempre. Em Todos os homens são mortais, Simone de Beauvoir representa um imaginário de vida sem fim, constituindo essa para o personagem o castigo supremo, o de não poder morrer. $\mathrm{O}$ grande filme de Ingmar Bergman, $O$ sétimo selo, fala da recusa da morte e do jogo estabelecido com ela para protelar o momento último dos 
personagens. Como a morte é uma realidade, embora não visível como entidade, podese ver que as elocubrações dos homens sobre o tema no terreno da arte vêm de modo geral, senão sempre, coloridas pelo fantástico, isso que Arriguci Jr chama de quinta essência da ficção ( $O$ escorpião encalacrado,1973, p. 167). A mulher-morte de Saramago ocupa todo o teatro quando, invisível, escuta o ensaio do concerto do violoncelista. Anda ao seu lado no táxi, sem que ele saiba, constituindo uma terrível metáfora do que é nossa vida, sempre enredada à morte, fato de que os adágios da sabedoria popular se apropriam.

Ainda no terreno da necessária fantasia para representar o que não tem existência material, lembre-se também o quadro de Brueghel, intitulado $O$ triunfo da morte onde dezenas de cadáveres já têm a caveira no lugar do rosto ao fim de uma batalha. Na ópera de Mozart, o personagem D. Giovanni vai para o inferno levado por uma estátua viva que é própria morte. Em outro nível quanto à qualidade e fazendo parte da indústria cultural, estão os filmes de terror onde a figura tradicional da morte é o centro, através de um discurso fantasioso. Um poema escrito em finais dos anos 1100 por um provável monge, Hélinand de Froidmont, faz uso de uma invocação à morte com quem dialoga, por assim dizer. Os poucos exemplos citados dão conta de que o imaginário da morte acompanha a vida desde que o ser humano toma consciência de si próprio e de sua fragilidade. Assim, Intermitências da morte vale-se igualmente do fantástico, porque não há outro modo de lidar com o que não constitui uma presença física, ainda que seja, paradoxalmente, uma realidade.

A ausência da morte em níveis reais constituiria uma tragédia, e é isso que vem para o romance. Necessária à perpetuação da vida, sua inexistência definitiva, aparente sonho da humanidade, mesmo daquela sua parte sofredora, traria o caos social. Num mundo onde a população aumenta a níveis assustadores enquanto o trabalho diminui de maneira mais assustadora ainda, a não-morte levantaria, de imediato, problemas como os que o romance de Saramago aborda de maneira irônica. Toda a indústria que necessariamente existe - e é preciso que exista - em função do final da vida entraria em crise. Transposta para a realidade, é uma verdade irretocável. "Nem tudo é festa, porém, ao lado de uns quantos que riem, sempre haverá os que choram, e, às vezes, como no presente caso, pelas mesmas razões. Importantes setores profissionais seriamente preocupados com a situação, já começaram a fazer chegar a quem de direito a expressão do seu descontentamento" (p.25). O narrador arrola então o setor funerário, as agências de seguro, os hospitais, os lares para idosos, que todos deixariam de ter razão de existir. Dos agentes do primeiro diz: estarem sentindo-se "brutalmente desprovidos de sua matéria prima" (p.25). "Uma terrível ameaça que vem pôr em perigo a sobrevivência de nossa indústria" (p. 32), é o que alega o setor de seguros de vida e morte. Quanto aos lares de idosos - "essas benfazejas instituições criadas em atenção à tranquiilidade das famílias que não têm tempo nem paciência para limpar os ranhos, atender aos esfíncteres fatigados" (p.29) - e aos hospitais - de onde "se relevavam as questões mais logísticas que propriamente sanitárias" (p.27), a quantidade de semi-mortos - ou com "a morte suspensa" (p.49) - a eliminação da morte constituir-se-ia num estorvo, mas sobretudo, no mundo do capital, um prejuízo em termos econômicos. Aqui, a escrita de Saramago, através de um discurso feito de ironia ácida, põe à mostra os mecanismos que regem o mundo desse tempo que é o nosso, o mundo da "cultura do dinheiro", repetindo o título de uma obra de Frederic Jameson. E com tal discurso fala verdades incontestáveis.

A respeito da verdade e das mentiras que são o cerne do gênero romance, há o belo ensaio de Vargas Llosa, A verdade pela mentira em que o autor afirma que as histórias que os romancistas contam é uma história que os historiadores não podem 
contar. Evidentemente, a afirmação de Vargas Llosa se prende ao seu conhecimento do ofício de historiador. Entretanto, o que se pode ler como mentira em Saramago é a sua invenção de uma situação impossível de acontecer, ou seja, a abolição da morte. Aqui o romance remete para a reflexão filosófica, para a indagação existencial. Quanto aos efeitos que a mentira traz na sua esteira, é a mais profunda verdade o que a ironia cruel de Saramago representa em Intermitências da morte.

Seria impossível uma obra de Saramago não atacar a Igreja que "como não podia deixar de ser, saiu à arena do debate montada no cavalo-de-batalha do costume, isto é, os desígnios de deus são o que sempre foram, inescrutáveis, o que, em termos correntes e algo manchados de impiedade verbal, significa que não nos é permitido espreitar pela frincha da porta do céu para ver o que se passa lá dentro" (p.75). A ironia corrosiva contra uma Igreja que aparece desde sempre enredada aos negócios da terra - leia-se do estado -, muito mais que aos do céu, aparece na figura do cardeal sendo obrigado a admitir para o primeiro-ministro "que se se acabasse a morte não poderia haver ressurreição, então não teria sentido haver igreja" e a conclusão óbvia do narrador é "que toda a história santa termina num beco sem saída" (p.36).

A solução para os mortos que não morrem de verdade neste estranho país atravessar a fronteira do país vizinho de onde a morte não se retirou - constitui uma crítica aguda ao mundo de pessoas supérfluas que ainda teimam a sobrevivência como imigrantes indesejados. Zygmunt Bauman, ao longo de muito de sua extensa obra sociológica sobre o mundo atual - moderno? pós-moderno? - acusa, de maneira mordaz, as políticas governamentais dos países ricos - cuja riqueza se fez da exploração dos países pobres - que fecham suas fronteiras para a imigração. Em Intermitências da morte, o narrador comenta a posição política dos países vizinhos àquele de onde a morte se retirou: "que não lhes fossem lá enterrar sem autorização esta nova espécie de imigrantes forçados" (p.63).

Saramago, na primeira parte do romance, descreve um mundo que identificamos como o mundo do capital. Contudo, na segunda, que é na verdade uma outra história, podendo ser lida independente do primeiro núcleo dramático, tem-se uma narrativa em que, salvo detalhes que descrevem o cotidiano de uma cidade com as marcas dadas pelo hotel, pelo táxi, entre outras, há uma certa intemporalidade. A parca, agora vista do seu próprio ponto de vista, ao contrário daquele dos humanos da primeira parte da obra, já não é um mistério. A morte anunciada - para retomar o título da novela de Garcia Márquez - pela carta fatal, habita entre os homens. "Está sentada, sozinha, no camarote de primeira ordem (...) O violoncelista reparou naquela mulher. Não foi único dos músicos a dar pela sua presença. (...) porque era bonita, porventura não a mais bonita da assistência (...) do público os homens tinham-na observado com dúbia curiosidade, as mulheres com zelosa inquietação" (p.191). Se aqui a carga de ironia diminui, não quer dizer que desapareça, pois a morte, agora transfigurada numa bela mulher que chama a atenção de todos, apaixona-se pelo homem que deve morrer como todos e que aparentemente se recusa a isso. Na verdade, a morte apaixona-se por um homem que é a imagem da vida. Pode-se ler, pois, uma metáfora do contraditório desejo de vida eterna, uma representação do imaginário de uma vida feliz sem morte, o que a história anterior desmente. "Entraram no quarto, despiram-se, e o que estava escrito que aconteceria, aconteceu enfim e outra vez, e outra ainda" (p. 207). Após queimar a carta lilás que trazia consigo, a mulher-morte volta para a cama. "Abraçou-se ao homem e sem compreender o que lhe estava a suceder, ela que nunca dormia, sentiu que o sono lhe fazia descair suavemente as pálpebras. No dia seguinte ninguém morreu" (p.207).

A leitura do romance de Saramago no seu todo, composto de duas partes unidas simbolicamente pela carta, constitui uma reflexão sobre o sentido da vida e da morte. 
Da morte como necessidade; da vida como o tempo a ser bem vivido e celebrado, o que certamente não é a realidade do mundo. Da morte, brota a vida, o seu renovo; ela habita ironicamente o mundo dos vivos. A ironia do fato de a morte se apaixonar pela vida quando se torna mulher é a representação da celebração. Mas "ninguém morreu” apenas naquele dia, onde termina a história. 